plasia and an anomaly of the lungs. The histological examination showed an oedematous derm and a decrease in the size and the number of hair follicles. The architecture of the thyroid vesicles was irregular and the colloid substance was missing, sometimes entirely, in these vesicles.

The epithelium of the bronchioles was flat atid detached from the basal membrane. These elements show the similarity between the disorders observed and the "syndrome of respiratory distress " or "Barker syndrom " described in pig, foal and man.

In this production unit the anomaly was only observed in the progeny of one boar, suggesting a genetic relationship. The determinism of this syndrome of respiratory distress was discussed.

\title{
Advantages and limits of the serological diagnosis of atrophic rhinitis
}

\author{
G. MARTINEAU $\left({ }^{1}\right)$, A. DEWAEIE $\left({ }^{1}\right)$, M. JOSSE $\left({ }^{2}\right)$ \\ (1) Chaire d'anatomie pathologique \\ ${ }^{2}$ ) Chaive de Bactériologie \\ Faculté de Médecine Vétérinaire UI.g., 45, rue des Vétérinaives, \\ I070 Bruxelles, Belgique
}

A serological inquiry to investigate the incidence of Bordetella bronchiseptica infection in pigs was conducted in a large Belgian slaughter house. A total of IIO3 sera were examined. Specific serum agglutinins were found in $9 \mathrm{I}$ p. I 00 of the samples with titrations equal or superior to I /40. In Belgium, $25 \mathrm{p}$. I oo of the animals are estimated to suffer from atrophic rhinitis. Thus a serious difference exists between the two data.

The difference may have several explanations: variable rhinopathogenic effect of different strains, variation in infection pressure, age of the animals at the time of infection, variation of environmental conditions.

The advantage and the limits of the serological diagnosis are discussed. It is important to determine whether a serologically negative animal may be admitted without risks and, on the other hand, to reject without restriction all serologically positive subjects. level.

The same questions are valid not only at the individual animal level, but also at the farm

In conclusion, on account of the current limits of the different methods of diagnosis suggested, only the SPF breedings afford adequate guarantees against atrophic rhinitis.

\section{Excretion of the virus of Aujeszky's disease through the genital tracts of boars. Persistence of the virus in boar semen}

\author{
P. VANNIER, B. GUEGUEN \\ Ministève de l'A griculture, Direction de la Qualité, Sevvices Vétérinaires, \\ Station de Pathologie Porcine, B.P. 9, 22440 Ploufragan (France) \\ I.T.P., I 49, rue de Bevcy, 75595 Paris Cedex I2
}

After experimental infection of three boars through the prepuce, excretion of the virus of Aujeszky's disease through the genital tracts was studied. Three and ter days after inoculation the virus was isolated in samples of semen and in the liquid used for prepuce cleaning. After Io 
days no virus was isolated in the samples obtained during the 79 days of experiment. An active growth of the virus was observed in the genital tracts of one boar since the titre of the viral suspension increased between two consecutive samplings. A possible virulicidal effect of semen on Aujeszky's virus was studied but could not be demonstrated. The short duration of the viral excretion was not due to an inactivation or neutralisation of the virus by the semen as the latter did not show any virulicidal effect and as no neutralizing activity could be observed in the different samples obtained.

\title{
Pig rotavirus enteritis in France
}

\author{
G. COR'THIER \\ Laboratoive de Pathologie Porcine, \\ Station de Virologie et d'Immunologie, I.N.R.A., \\ $7885^{\circ}$ Thiverval Grignon (France)
}

This paper is divided into two parts. The purpose of the first one was to give a general survey of pig rotavirus enteritis. The etiology, pathogeny, clinics, epidemiology, diagnosis and prophylaxy are discussed. The second part deals with the importance of this disease in France. The infection is observed very frequently: more than $83 \mathrm{p}$. I 00 of the pigs have a positive serology.

Rotavirus was isolated and characterized in some faeces of enteritic pigs. Inoculation of the different strains into colostrum deprived piglets led to lethal enteritis (death within 3 days).

\section{Swine dysentery, a disease due to spontaneous contamination in pens. Clinical data and diagnosis}

\author{
J. P. RAYNAUD, G. BRUNAULT, J. PHILIPPE;
}

Station de Recherche et de Développement Vétérinaive et Nutrition Animale, Pfizer International, 37400 Amboise (France)

Eighty three young weaned piglets weighing $19 \mathrm{~kg}$ on an average were put individually in pens already contaminated by dysenteric animals. 90 p. I 00 showed a typical disease and the morbidity was very high in those conditions. Among the dysenteric animals 80 p. too died and $20 \mathrm{p}$. Ioo were spontaneously cured. In animals which were going to die, dysentery occurred I 3 days after the beginning of the contamination and lasted 8 days. Before the death (23rd day) 2.5 days of diarrhoea plus mucus were noted (only $49 \mathrm{p}$. I 00 of the animals). In animals which were going to be cured spontaneously dysentery occurred on day 14 and lasted for to days. Before being completely cured (day 39) 92 p. Ioo of the animals - showed 7 days of diarthoea with mucus. To confirm the etiology it is useful to give an estimate of the presence of Treponema and Campylobacter on dried smears and to number Treponema and Balantidium coli on fresh smears. In a sure diagnosis of the disease it is necessary to isolate the Treponema hyodysenteriae. strain and to evidence its hemolytic properties and its pathogenicity in piglets. 